\title{
Ascorbic acid coadministration with artesunate-amodiaquine, up-regulated antioxidant enzymes gene expression in bone marrow cells and elicited biochemical changes in Plasmodium berghei-infected mice
}

\author{
Osamudiamen Ebohon $^{1}\left[\right.$ Francis Irabor $^{1}$ [ $\cdot$ Ehimwenma Sheena Omoregie ${ }^{2}$
}

Received: 19 October 2020 / Accepted: 22 December 2020 / Published online: 6 January 2021

(c) The Author(s) 2021 OPEN

\begin{abstract}
One of the hallmarks of malaria infection is oxidative stress. This study was aimed at investigating the potential effects of coadministering a therapeutic dose of artesunate-amodiaquine (AS/AQ) with Vitamin C (Vit C) orally on some biochemical parameters and antioxidant enzymes gene expression in bone marrow cells of Plasmodium berghei-infected mice. Thirty male Swiss albino mice were divided into five groups of six mice each as follows: Basal control (not infected with $P$. berghei), Untreated (P. berghei-infected without treatment), Vit C, AS/AQ and AS/AQ + Vit C combination treated mice. Treatment was done twice daily for three consecutive days. Complete parasite clearance was observed on the second day of treatment in $A S / A Q$ and $A S / A Q+V i t C$ combination treated $P$. berghei-infected mice. Serum albumin and bilirubin levels were higher in the AS/AQ + Vit C combination treated P. berghei-infected mice compared with those treated with AS/ $\mathrm{AQ}$ only. Artesunate-amodiaquine $+\mathrm{Vit} \mathrm{C}$ combination increased superoxide dismutase activity and reduced hydrogen peroxide and malondialdehyde levels in $P$. berghei-infected mice when compared with the mice treated with only AS/AQ. Furthermore, AS/AQ + Vit C combination significantly up-regulated catalase and glutathione peroxidase-1 (GPx-1) mRNA expression compared with the mice treated with only AS/AQ. This is the first report linking AS/AQ to antioxidant enzyme gene expression in bone marrow cells. Our findings showed that $A S / A Q$ and Vit $C$ coadministration may be beneficial as it ameliorated oxidative stress and up-regulated antioxidant enzyme gene expression in P. berghei-infected mice.
\end{abstract}

Keywords Artesunate-amodiaquine - Vitamin C · Oxidative stress · Gene expression · Antioxidants · Malaria

\section{Background}

Malaria, a disease caused by the Plasmodium parasite is still a burden causing morbidity and mortality particularly in Africa. In 2019, Africa alone accounted for about 94\% of the 229 million cases of malaria reported worldwide. Similarly, this region accounted for about $94 \%(384,000)$ of all malaria deaths $(409,000)$ worldwide [1]. Nigeria, the most populated country in Africa, is responsible for $27 \%$ of the total malaria burden and $23 \%$ of malaria deaths [1]. The female Anopheles mosquito is the vector for malariacausing parasite hence, the disease is transmitted during a blood meal by this mosquito. Of the five species of Plasmodium causing malaria, Plasmodium falciparum is the most virulent and it is also the most dominant in Africa.

\footnotetext{
$\triangle$ Osamudiamen Ebohon, ebohonosamudiamen@yahoo.com; Francis Irabor, francis.irabor@yahoo.com; Ehimwenma Sheena Omoregie, ehimwenma.omoregie@uniben.edu| 'Biochemistry Programme, Department of Biological and Chemical Sciences, Faculty of Natural and Applied Sciences, Michael and Cecilia Ibru University, P.M.B. 100, Agbarha-Otor, Ughelli North, Delta State, Nigeria. ${ }^{2}$ Malaria Research, Molecular Biology and Toxicology Unit, Department of Biochemistry, Faculty of Life Sciences, University of Benin, P.M.B 1154, Benin City, Nigeria.
} 
During malaria infection, the host and parasite are under oxidative stress resulting from the increased production of reactive oxygen species (ROS) from the hosts activated neutrophils and the toxic free haem released during the breakdown of haemoglobin by the parasite [2]. Some studies have shown that reactive oxygen and nitrogen species involved with oxidative stress plays pertinent role in the development of systemic complications caused by malaria [3]. Malaria infection, results in an increased production of free radicals in some cells. For example, Guha et al. [4] reported that malaria infection induces hydroxyl radical production in the liver while Atamma et al. [5] observed that Plasmodium falciparum infected erythrocytes produces twice as much hydrogen peroxide and hydroxyl radicals compared with uninfected erythrocytes. Malaria parasites are highly sensitive to oxidative stress and under certain conditions, manipulating the nutritional state of the host such as supplementing with riboflavin and Vitamin C may affect the course of malarial infection [6].

The WHO recommended artemisinin-based combination therapies (ACTs) as the first line treatment for uncomplicated malaria [7]. Currently, there are six approved ACTs by the WHO. Viz: artesunate-mefloquine, artemether-lumefantrine, dihydroartemisinin-piperaquine, artesunate-sulfadoxine-pyrimethamine, artesunate-amodiaquine [8] and artesunate-pyronaridine [9]. In Nigeria, artemether-lumefantrine and artesunate-amodiaquine are the most widely used ACTs. The artemisinin derivatives of these combination therapies are fast acting and can result in rapid parasite clearance, while their partner drugs are longer lasting and can eliminate residual parasites. The interaction between the endoperoxide bridge in artemisinin and haem (from haemoglobin degradation) results in the generation of highly reactive radicals that brings about parasite death.

Sometimes during malaria treatment, antimalarials are prescribed along with other drugs like Vitamin C and Vitamin supplements [10]. This seems to make sense, as the Vitamin C which is a water soluble antioxidant would help manage oxidative stress already implicated in malaria infection by mopping up the free radicals generated. This action of Vitamin $\mathrm{C}$ is a direct opposite to the mode of action of artemisinins. Most scientific investigations have focused on the effect of coadministration of artemisinin with antioxidants $[11,12]$. Artemisinin is no longer used as monotherapy but rather in combination with other antimalarials and there are limited studies on the effect of antioxidants on these ACTs. Therefore, the aim of this study was to evaluate the potential effects of therapeutic dose of artesunate-amodiaquine (AS/AQ) and Vitamin C oral coadministration in P. berghei-infected mice. Furthermore, the study identified the changes in antioxidant enzymes gene expression in bone marrow cells of $P$. berghei-infected mice.

\section{Materials and methods}

\subsection{Drugs and chemicals}

Drugs used for this study were artesunate-amodiaquine (Camosunate, Front Pharmaceutical PLC, Anhui, China) and Vitamin C (Em-Vitamin $C^{\circ}$, Emzor Pharmaceutical Industries Limited, Lagos, Nigeria). Methanol, trichloroacetic acid (TCA), thiobarbituric acid (TBA), hydrochloric acid, epinephrine, sodium carbonate decahydrate, sodium hydrogen trioxocarbonate, xylenol orange, sorbitol, sulphuric acid, ammonium ferrous sulphate, hydrogen peroxide were gotten from Sigma-Aldrich (Germany). All chemicals and reagents used were of analytical grade.

\subsection{Experimental animals}

Thirty male Swiss albino mice (19-23 g), obtained from the Nigerian Institute of Medical Research (NIMR), Lagos State, Nigeria were used for this study. The mice were housed under standard laboratory conditions in the vivarium of Michael and Cecilia Ibru University at temperature $27 \pm 2^{\circ} \mathrm{C}$, a $12 \mathrm{~h}$ light: $12 \mathrm{~h}$ dark cycle in clear polypropylene cages lined with wood chip beddings. They had access to commercial mash (Pfizer Livestock Feeds, Lagos Nigeria) and water ad libitum. The mice were acclimatized for 1 week before the commencement of the experiment. Ethical approval for this study was granted by the Institutional Ethics Review Committee, Michael and Cecilia Ibru University (ethics approval number: $M C I U / E T H / 20 / 05)$ in accordance with the Guide for the Care and Use of Laboratory Animals published by the National Academy of Sciences (Eight edition).

\subsection{Malaria parasites and inoculation}

Chloroquine-sensitive strain of rodent parasite, Plasmodium berghei NK65 maintained in mice was obtained from the Malaria Laboratory, Department of Biochemistry at the Nigerian Institute of Medical Research (NIMR) Lagos, Nigeria. The parasite was kept alive by continuous intra-peritoneal passage in healthy mice. Blood from a single donor mouse with parasitaemia $25 \%$ was obtained via cardiac puncture into heparinized tubes and was diluted with normal saline to have inoculums containing approximately $1 \times 10^{7}$ infected erythrocytes. 
Aliquot of $0.2 \mathrm{~mL}$ of standard inoculums $\left(1 \times 10^{7}\right.$ Plasmodium berghei strain NK 65 parasitized erythrocytes) were used to infect other mice where necessary.

\subsection{Experimental design}

Thirty (30) male Swiss albino mice were randomly divided into 5 groups of 6 mice each using the Rand () function in Microsoft Excel. On the first day of the experiment (termed 'day $0^{\prime}$ '), all mice were injected intraperitoneally with standard inoculums of $P$. berghei containing $1 \times 10^{7}$ infected erythrocytes except the basal control group. Seventy-two (72) hours later, treatment began for all the groups. Treatment was done orally twice daily for three consecutive days. The research team monitored the animals twice daily. Percentage parasitaemia level was monitored daily before treatment by thin blood film microscopic examination. A total of 2500 red blood cells were counted to estimate parasitaemia. Percentage parasitaemia was determined using the formula below. The experimental plan of this study is shown in Table 1. The investigators who designed the study, administered the treatments to the different groups, conducted the experiment and analysed the data generated were not blinded.

$\%$ Parasitaemia $=\frac{\text { Number of parasitized erythrocytes }}{\text { Total number of erythrocytes }} \times 100$

\subsection{Sample collection and euthanasia}

Blood samples were collected from the animals via aortic puncture under anaesthesia (chloroform vapour), $24 \mathrm{~h}$ after the last exposure to treatments. The animals were fasted overnight ( $12 \mathrm{~h}$ ) before samples were collected. The blood samples were collected without anticoagulants, allowed to clot for $30 \mathrm{~min}$ and then centrifuged at $2000 \mathrm{rpm}$ for $10 \mathrm{~min}$ to obtain serum. A portion (1 g) of the harvested organs (liver and kidney) were homogenized in $5 \mathrm{~mL}$ of ice-cold $0.1 \mathrm{M}$ phosphate buffer, $\mathrm{pH} 7.4$ using a Potter-Elvehjem homogenizer. Post-mitochondrial fractions were obtained by centrifuging the homogenates at $12,000 \mathrm{~g}$ for $15 \mathrm{~min}$ at $4{ }^{\circ} \mathrm{C}$. After sample collection, the anaesthetized mice were euthanized via cervical dislocation and death was confirmed. The carcasses of the mice were disposed of appropriately using a burial pit.

\subsection{Biochemical assays}

\subsubsection{Estimation of hepatic and renal function indices}

Randox test kits were used to determine serum alanine aminotransferase (ALT) and aspartate aminotransferase (AST) activities using the method of Reitman and Frankel [13] as well as serum albumin and total protein levels according to the method of Grant et al. [14] and Tietz [15] respectively. Total and direct bilirubin were estimated using Agappe diagnostic kits according to the method of Walter and Gerard [16] and Annino [17]. To evaluate renal function indices, Agappe diagnostic kits were used to estimate urea level by Berthelot method [18] and creatinine was evaluated with the method of Allen et al. [19]. The manufacturer's protocols were strictly followed in all instances.

\subsubsection{Estimation of oxidative stress indices}

Superoxide dismutase (SOD) activity was determined using the method of Misra and Fridovich [20]. Lipid peroxidation was evaluated in terms of malondialdehyde (MDA) formation following the protocol of Buege and Aust [21] while hydrogen peroxide $\left(\mathrm{H}_{2} \mathrm{O}_{2}\right)$ was estimated using the method of Wolff [22].

Table 1 Experimental design

\begin{tabular}{|c|c|}
\hline Groups & Experimental plan \\
\hline Basal control & $\begin{array}{l}\text { Was not infected with } P \text {. berghei but was administered } 0.2 \mathrm{~mL} \text { of the vehicle (distilled water) orally twice daily for three } \\
\text { consecutive days }\end{array}$ \\
\hline Untreated & Was infected with $P$. berghei and orally administered $0.2 \mathrm{~mL}$ of distilled water twice daily for three consecutive days \\
\hline Vitamin C & $\begin{array}{l}\text { Was infected with } P \text {. berghei and orally administered Vitamin C ( } 2.73 \mathrm{mg} / \mathrm{kg} \text { body weight) in } 0.2 \mathrm{~mL} \text { of distilled water } \\
\text { twice daily for three consecutive days }\end{array}$ \\
\hline AS/AQ & $\begin{array}{l}\text { Was infected with } P \text {. berghei and orally administered artesunate }(1.82 \mathrm{mg} / \mathrm{kg}) \text {-amodiaquine }(5.45 \mathrm{mg} / \mathrm{kg}) \text { in } 0.2 \mathrm{~mL} \text { of } \\
\text { distilled water twice daily for three consecutive days }\end{array}$ \\
\hline$A C$ & $\begin{array}{l}\text { Was infected with } P . \text { berghei and orally administered artesunate }(1.82 \mathrm{mg} / \mathrm{kg}) \text {-amodiaquine }(5.45 \mathrm{mg} / \mathrm{kg}) \text { in combinati } \\
\text { with Vitamin C ( } 2.73 \mathrm{mg} / \mathrm{kg}) \text { in } 0.2 \mathrm{~mL} \text { of distilled water twice daily for three consecutive days }\end{array}$ \\
\hline
\end{tabular}

$A S / A Q$ Artesunate-amodiaquine 


\subsection{Gene expression study}

\subsubsection{Harvesting bone marrow of mice}

Both femurs of each mice were excised, cleansed to remove muscles and other tissues and then cut open at both ends. Bone marrow cells were harvested from the femurs by flushing out the marrow with complete RPMI 1640 media (Sigma-Aldrich Germany) supplemented with $10 \%$ fetal bovine serum (Sigma-Aldrich Germany) using a 26-gauge needle into a sterile Eppendorf tube. The bone marrow cells were pelleted by centrifugation in microcentrifuge tubes and then resuspended in RNAlater (SigmaAldrich Germany) to preserve the RNA until isolation.

\subsubsection{Total RNA isolation, cDNA conversion and PCR amplification}

Total RNA isolation, cDNA conversion, PCR amplification and agarose gel electrophoresis was done following the method described by Omotuyi et al. [23] as reported by Ebohon et al. [24]. Primers targeting exon-exon junction was designed using Primer3 software [25]. All oligonucleotides synthesis was done by Inqaba Biotec, Pretoria, South Africa. Primers used for the targeted genes [catalase, superoxide dismutase-1 (Cu/Zn-SOD), glutathione peroxidase-1 (GPx-1) and $\beta$-Actin] are listed in Table 2. In-gel amplicon bands images captured on camera were processed on Keynote platform. Gel density quantification was done using Image-J software [26]. Each point represent relative expression [(test gene band intensity/internal control band intensity) ${ }^{*} 100$ ] plotted using Numbers software (Mac OSX version).

\subsection{Statistical analysis}

Statistical package for social science (SPSS) for windows, version 16.0 (SPSS Inc., Chicago, IL, USA) was used to carry out all statistical analysis. The results obtained were expressed as Mean \pm SEM. One way analysis of variance (ANOVA) test was used to determine significant differences between the groups and Post Hoc Multiple Comparison Test was done using Tukey's HSD (honest significant difference). Statistical significance was declared when $P$ value was less than 0.05 .

\section{Results}

\subsection{Profile of percentage parasitaemia of $P$. berghei infected mice following administration of artesunate-amodiaquine (AS/AQ), Vitamin C and their combination}

Figure 1 shows the effect of artesunate-amodiaquine, Vitamin $C$ and their combination on the percentage parasitaemia of $P$. berghei-infected mice. Day 0 was predrug treatment while day 1-3 were post-drug treatment. The artesunate-amodiaquine and artesunate-amodiaquine + Vitamin C combination treated $P$. bergheiinfected mice showed complete parasite clearance while the untreated ( $P$. berghei-infected, not treated) and

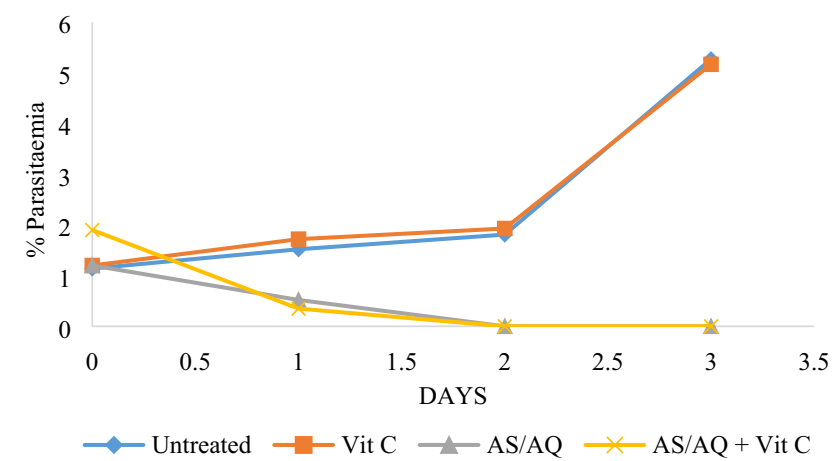

Fig. 1 Effect of Vitamin C (Vit C), artesunate-amodiaquine (AS/AQ) and their combination on parasite clearance in $P$. berghei-infected mice. Untreated $=$ infected with $P$. berghei and not treated
Table 2 Primer sequences

\begin{tabular}{|c|c|c|c|c|}
\hline Target genes & Accession numbers & Primer sequences & $\operatorname{Tm}\left({ }^{\circ} \mathrm{C}\right)$ & $\begin{array}{l}\text { Amplicon } \\
\text { size (bp) }\end{array}$ \\
\hline Catalase & NM_012520.2 & $\begin{array}{l}\text { Forward }\left(5^{\prime}-3^{\prime}\right) \text { : TCACCTGAAGGACCCTGACA } \\
\text { Reverse }\left(5^{\prime}-3^{\prime}\right) \text { : TCCATCTGGAATCCCTCGGT }\end{array}$ & 55 & 103 \\
\hline $\mathrm{Cu} / \mathrm{Zn}-\mathrm{SOD}$ & NM_017050.1 & $\begin{array}{l}\text { Forward (5'-3'): TTTTGCTCTCCCAGGTTCCG } \\
\text { Reverse (5'-3'): GGTTCACCGCTTGCCTTCT }\end{array}$ & 60 & 133 \\
\hline GPx-1 & NM_030826.4 & $\begin{array}{l}\text { Forward }\left(5^{\prime}-3^{\prime}\right): \text { ATCAGTTCGGACATCAGGAGA } \\
\text { Reverse }\left(5^{\prime}-3^{\prime}\right): \text { TCACCATTCACCTCGCACTT }\end{array}$ & 59 & 124 \\
\hline$\beta$-Actin & NM_031144.3 & $\begin{array}{l}\text { Forward (5'-3'): CTGGCTCCTAGCACCATGAA } \\
\text { Reverse }\left(5^{\prime}-3^{\prime}\right) \text { : CGCAGCTCAGTAACAGTCCG }\end{array}$ & 61 & 192 \\
\hline
\end{tabular}

$\mathrm{Cu} / \mathrm{Zn}-\mathrm{SOD}=$ Superoxide dismutase- $1, \mathrm{GPx}-1$ = glutathione peroxidase- 1

SN Applied Sciences 
Vitamin C treated mice showed increased parasitaemia at day 3 .

\subsection{Hepatic and renal function indices of $P$. berghei-infected mice following administration of artesunate-amodiaquine (AS/AQ), Vitamin C and their combination}

Serum AST activity was significantly $(p<0.05)$ lower in artesunate-amodiaquine + Vitamin $C$ combination treated mice when compared with the untreated mice ( $P$. berghei-infected, not treated) (Table 3). The basal control and all treated mice had a nonsignificant decrease in serum ALT activity in comparison with the untreated $P$. berghei-infected mice. Albumin (ALB) level of the artesunate-amodiaquine + Vitamin $C$ combination treated $P$. berghei-infected mice was significantly higher $(p<0.05)$ than the untreated and artesunate-amodiaquine treated mice. Total bilirubin was significantly higher in the artesunate-amodiaquine + Vitamin C combination treated mice compared with the mice treated with only artesunate-amodiaquine. The amount of urea in the artesunate-amodiaquine + Vitamin C combination treated mice was significantly lower than the untreated, artesunate-amodiaquine, Vitamin $\mathrm{C}$ and basal control groups while a nonsignificant decrease was observed in creatinine level (Table 3).

\subsection{Oxidative stress indices and organ/body weight ratio of $P$. berghei-infected mice following administration of artesunate- amodiaquine (AS/AQ), Vitamin $C$ and their combination}

A significant $(p<0.05)$ increase in hepatic SOD activity was observed in artesunate-amodiaquine + Vitamin $C$ combination treated $P$. berghei-infected mice when compared with the untreated mice (Table 4).
Table 3 Hepatic and renal function indices of $P$. berghei-infected mice after administration of artesunateamodiaquine (AS/AQ), Vitamin $\mathrm{C}$ and their combination

\begin{tabular}{lcclcc}
\hline & Basal control & Untreated & Vitamin C & AS/AQ & AS/AQ +Vitamin C \\
\hline AST (U/L) & $75.29 \pm 8.26^{\mathrm{ab}}$ & $97.99 \pm 7.23^{\mathrm{a}}$ & $91.19 \pm 4.76^{\mathrm{a}}$ & $82.04 \pm 8.61^{\mathrm{ab}}$ & $64.79 \pm 5.14^{\mathrm{b}}$ \\
ALT (U/L) & $10.16 \pm 1.05^{\mathrm{a}}$ & $15.20 \pm 4.80^{\mathrm{a}}$ & $9.80 \pm 2.10^{\mathrm{a}}$ & $9.40 \pm 1.14^{\mathrm{a}}$ & $10.07 \pm 0.77^{\mathrm{a}}$ \\
$\mathrm{TP}(\mathrm{g} / \mathrm{dL})$ & $2.60 \pm 0.03^{\mathrm{a}}$ & $3.69 \pm 0.37^{\mathrm{b}}$ & $3.60 \pm 0.06^{\mathrm{ab}}$ & $4.31 \pm 0.20^{\mathrm{b}}$ & $3.85 \pm 0.27^{\mathrm{b}}$ \\
ALB (g/dL) & $1.41 \pm 0.07^{\mathrm{a}}$ & $1.28 \pm 0.02^{\mathrm{a}}$ & $1.50 \pm 0.12^{\mathrm{ab}}$ & $1.41 \pm 0.07^{\mathrm{a}}$ & $2.02 \pm 0.21^{\mathrm{b}}$ \\
$\mathrm{TB}(\mathrm{mg} / \mathrm{dL})$ & $0.19 \pm 0.03^{\mathrm{a}}$ & $0.54 \pm 0.03^{\mathrm{c}}$ & $0.46 \pm 0.06^{\mathrm{b}}$ & $0.27 \pm 0.02^{\mathrm{a}}$ & $0.41 \pm 0.00^{\mathrm{b}}$ \\
DB (mg/dL) & $0.12 \pm 0.04^{\mathrm{a}}$ & $0.43 \pm 0.04^{\mathrm{a}}$ & $0.33 \pm 0.13^{\mathrm{a}}$ & $0.19 \pm 0.03^{\mathrm{a}}$ & $0.33 \pm 0.08^{\mathrm{a}}$ \\
Urea (mg/dL) & $11.62 \pm 0.41^{\mathrm{b}}$ & $16.07 \pm 1.20^{\mathrm{c}}$ & $13.31 \pm 1.21^{\mathrm{bc}}$ & $11.43 \pm 1.32^{\mathrm{b}}$ & $6.44 \pm 0.82^{\mathrm{a}}$ \\
Creatinine (mg/dL) & $0.35 \pm 0.01^{\mathrm{a}}$ & $0.46 \pm 0.08^{\mathrm{a}}$ & $0.32 \pm 0.03^{\mathrm{a}}$ & $0.29 \pm 0.03^{\mathrm{a}}$ & $0.32 \pm 0.09^{\mathrm{a}}$
\end{tabular}

Values are expressed as mean $\pm S E M, n=6$ mice/group. Values in the same row with different superscripts are significantly different $(p<0.05)$ while those with same superscripts are not significantly different. Basal control = not infected with $P$. berghei and not treated, Untreated = infected with $P$. berghei and not treated, $A L T=$ Alanine aminotransferase,$A S T=$ Aspartate aminotransferase,$T P=$ Total protein, $\mathrm{ALB}=$ Albumin, $\mathrm{TB}=$ Total bilirubin, $\mathrm{DB}=$ Direct bilirubin, $\mathrm{AS} / \mathrm{AQ}=$ Artesunate-amodiaquine

Table 4 Oxidative stress indices and organ/body weight ratio of $P$. berghei-infected mice after administration of artesunate-amodiaquine (AS/AQ), Vitamin $C$ and their combination

\begin{tabular}{lccccc}
\hline & Basal control & Untreated & Vitamin C & AS/AQ & AS/AQ+Vitamin C \\
\hline Hepatic SOD (unit/g protein) & $0.19 \pm 0.01^{\mathrm{ab}}$ & $0.12 \pm 0.02^{\mathrm{a}}$ & $0.17 \pm 0.02^{\mathrm{ab}}$ & $0.15 \pm 0.01^{\mathrm{ab}}$ & $0.20 \pm 0.02^{\mathrm{b}}$ \\
Renal SOD (unit/g protein) & $0.70 \pm 0.06^{\mathrm{c}}$ & $0.32 \pm 0.05^{\mathrm{a}}$ & $0.64 \pm 0.03^{\mathrm{bc}}$ & $0.42 \pm 0.04^{\mathrm{ab}}$ & $0.46 \pm 0.06^{\mathrm{ab}}$ \\
Hepatic $\mathrm{H}_{2} \mathrm{O}_{2}(\mu \mathrm{M})$ & $6.05 \pm 0.45^{\mathrm{b}}$ & $8.35 \pm 0.60^{\mathrm{c}}$ & $6.53 \pm 0.28^{\mathrm{b}}$ & $6.40 \pm 0.19^{\mathrm{b}}$ & $4.25 \pm 0.50^{\mathrm{a}}$ \\
Renal $\mathrm{H}_{2} \mathrm{O}_{2}(\mu \mathrm{M})$ & $3.85 \pm 0.36^{\mathrm{a}}$ & $4.95 \pm 0.28^{\mathrm{a}}$ & $4.38 \pm 0.77^{\mathrm{a}}$ & $4.13 \pm 0.02^{\mathrm{a}}$ & $4.89 \pm 0.16^{\mathrm{a}}$ \\
Hepatic MDA (moles MDA/mg protein) & $0.29 \pm 0.04^{\mathrm{a}}$ & $0.34 \pm 0.01^{\mathrm{a}}$ & $0.31 \pm 0.07^{\mathrm{a}}$ & $0.32 \pm 0.03^{\mathrm{a}}$ & $0.30 \pm 0.01^{\mathrm{a}}$ \\
Renal MDA (moles MDA/mg protein) & $0.48 \pm 0.08^{\mathrm{a}}$ & $0.89 \pm 0.04^{\mathrm{b}}$ & $0.72 \pm 0.06^{\mathrm{ab}}$ & $0.66 \pm 0.08^{\mathrm{ab}}$ & $0.60 \pm 0.01^{\mathrm{a}}$ \\
Liver/body weight ratio & $0.049 \pm 0.002^{\mathrm{a}}$ & $0.090 \pm 0.003^{\mathrm{b}}$ & $0.087 \pm 0.01^{\mathrm{b}}$ & $0.056 \pm 0.004^{\mathrm{a}}$ & $0.064 \pm 0.004^{\mathrm{a}}$ \\
Spleen/body weight ratio & $0.010 \pm 0.001^{\mathrm{a}}$ & $0.025 \pm 0.002^{\mathrm{b}}$ & $0.027 \pm 0.002^{\mathrm{b}}$ & $0.018 \pm 0.002^{\mathrm{ab}}$ & $0.018 \pm 0.003^{\mathrm{ab}}$ \\
Kidney/body weight ratio & $0.016 \pm 0.001^{\mathrm{a}}$ & $0.016 \pm 0.001^{\mathrm{a}}$ & $0.016 \pm 0.000^{\mathrm{a}}$ & $0.014 \pm 0.001^{\mathrm{a}}$ & $0.016 \pm 0.000^{\mathrm{a}}$ \\
\hline
\end{tabular}

Values are expressed as mean $\pm S E M, n=6$ mice/group. Values in the same row with different superscripts are significantly different $(p<0.05)$ while those with same superscripts are not significantly different. Basal control=not infected with $P$. berghei and not treated, Untreated $=$ infected with $P$. berghei and not treated, $\mathrm{SOD}=$ Superoxide dismutase, $\mathrm{H}_{2} \mathrm{O}_{2}=$ Hydrogen peroxide, MDA $=$ Malondialdehyde, $\mathrm{AS} /$ $\mathrm{AQ}=$ Artesunate-amodiaquine 
The artesunate-amodiaquine + Vitamin C combination treated mice had a nonsignificant increase in hepatic SOD activity in comparison with artesunate-amodiaquine treated mice. Similarly, renal SOD activity was nonsignificantly higher in artesunate-amodiaquine and artesunate-amodiaquine + Vitamin $C$ combination treated $P$. berghei-infected mice in contrast to the untreated mice. A significant decrease in hepatic $\mathrm{H}_{2} \mathrm{O}_{2}$ was observed in artesunate-amodiaquine + Vitamin $\mathrm{C}$ combination treated mice when compared with the other treatment groups. Hepatic MDA level was lower in the treatment groups when compared with the untreated mice; however, this decrease was not significant. Renal MDA level in the artesunate-amodiaquine + Vitamin C combination treated $P$. berghei-infected mice was significantly $(p<0.05)$ lower than the untreated mice.

Artesunate-amodiaquine and its combination with Vitamin $C$ resulted in a significant $(p<0.05)$ decrease in liver/body weight ratio in comparison with the Vitamin $C$ and untreated groups (Table 4). A non-significant change in organ/body weight ratio was observed in artesunate-amodiaquine + Vitamin C combination treated mice when compared with the mice treated with only artesunate-amodiaquine.

\subsection{Gene expression of bone marrow cells of $P$. berghei-infected mice after administration of artesunate-amodiaquine (AS/AQ), Vitamin C and their combination}

The effect of the administration of Vitamin C, artesunate-amodiaquine (AS/AQ) and their combination on antioxidant enzymes gene expression of bone marrow cells of $P$. berghei-infected mice are shown in Figs. 2, 3 and

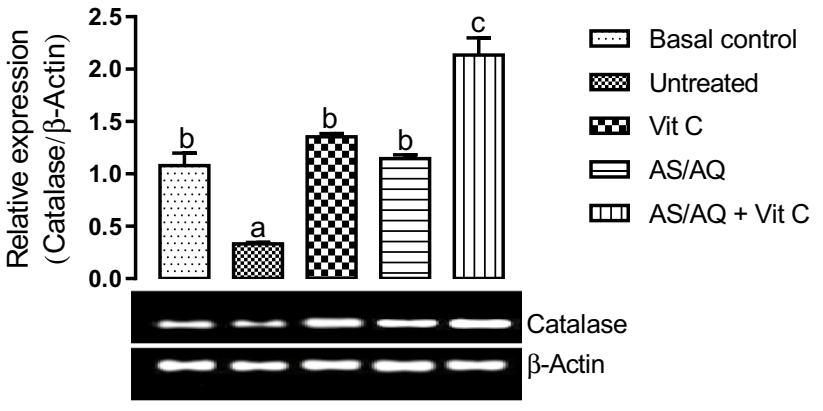

Fig. 2 Effect of Vitamin C (Vit C), artesunate-amodiaquine (AS/AQ) and their combination on catalase gene expression of bone marrow cells of $P$. berghei-infected mice. The figure represents the densitometric analysis and mRNA gel image of catalase gene. $\beta$-Actin was used as the loading control. Values are mean $\pm S E M, n=5$ mice/ group. Columns with different alphabet are significantly different $(p<0.05)$. Basal control $=$ not infected with $P$. berghei and not treated, Untreated $=$ infected with $P$. berghei and not treated

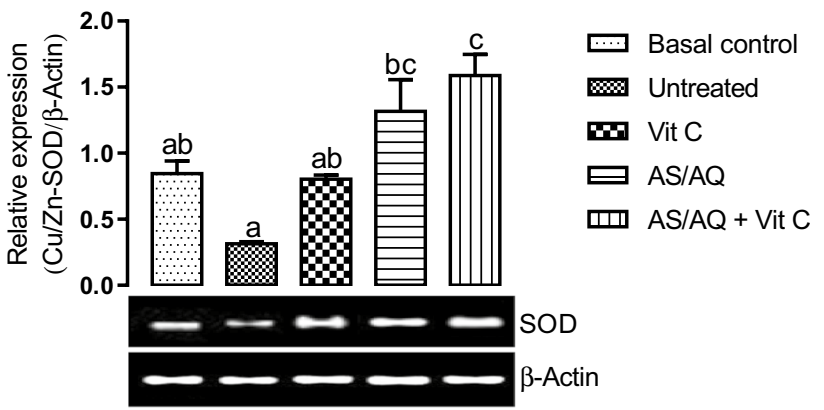

Fig. 3 Effect of Vitamin C (Vit C), artesunate-amodiaquine (AS/AQ) and their combination on superoxide dismutase (Cu/Zn-SOD) gene expression of bone marrow cells of $P$. berghei-infected mice. The figure represents the densitometric analysis and mRNA gel image of SOD gene. $\beta$-Actin was used as the loading control. Values are mean \pm SEM, $n=5$ mice/group. Columns with different alphabet are significantly different $(p<0.05)$. Basal control $=$ not infected with $P$. berghei and not treated, Untreated =infected with $P$. berghei and not treated

4. Antioxidant enzymes [catalase, superoxide dismutase (Cu/Zn-SOD) and glutathione peroxidase-1 (GPx-1)] mRNA expression were down-regulated in the untreated mice ( $P$. berghei-infected, not treated) when compared with the basal control and the other groups. Catalase mRNA level of the Vitamin $C$ and artesunate-amodiaquine treated mice were not significantly different from the basal control; however, artesunate-amodiaquine + Vitamin C combination treated $P$. berghei-infected mice had a significantly $(p<0.05)$ higher catalase mRNA expression in comparison with the untreated, basal control and the other treatment groups (Fig. 2). Similarly, artesunate-amodiaquine + Vitamin C combination treated mice had a significantly higher

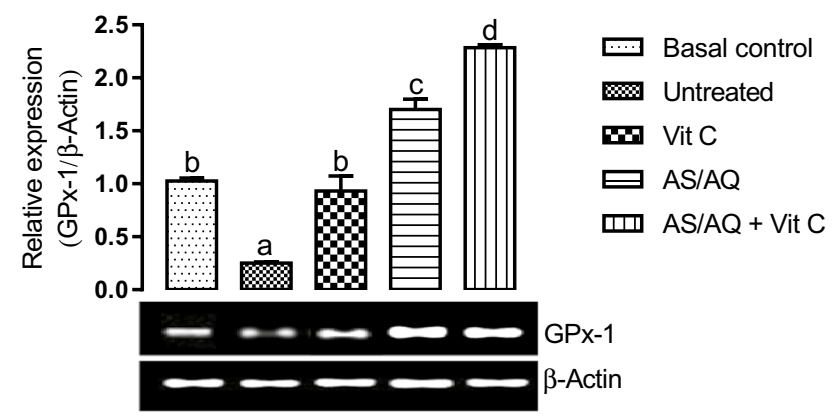

Fig. 4 Effect of Vitamin C (Vit C), artesunate-amodiaquine (AS/AQ) and their combination on glutathione peroxidase-1 (GPx-1) gene expression of bone marrow cells of $P$. berghei-infected mice. The figure represents the densitometric analysis and mRNA gel image of GPx-1 gene. $\beta$-Actin was used as the loading control. Values are mean \pm SEM, $n=5$ mice/group. Columns with different alphabet are significantly different $(p<0.05)$. Basal control $=$ not infected with $P$. berghei and not treated, Untreated=infected with $P$. berghei and not treated 
$\mathrm{Cu} / \mathrm{Zn}$-SOD gene expression when compared with the other groups; however, when compared with the mice treated with only artesunate-amodiaquine, this up-regulation was not significant (Fig. 3). Finally, GPx-1 gene was significantly $(p<0.05)$ up-regulated in artesunate-amodiaquine and artesunate-amodiaquine +Vitamin C combination treated $P$. berghei-infected mice compared with the untreated, basal control and Vitamin C groups (Fig. 4). Additionally, artesunate-amodiaquine + Vitamin C combination resulted in a significantly higher GPx-1 gene expression in comparison with the mice treated with only artesunate-amodiaquine. For the gene expression study, $\mathrm{n}=5$ mice/group because the first set of samples collected were contaminated.

\section{Discussion}

Artemisinin-based combination therapies (ACTs) are the first line drugs for the treatment of uncomplicated malaria in Africa [27]. Presently in Nigeria, artemetherlumefantrine and artesunate-amodiaquine are the most widely used ACTs. These drugs are relatively safe and are fast acting against malaria parasite. One of the hallmarks of malaria infection is oxidative stress hence, one may assume a beneficial effect when antimalarials are taken with antioxidants. This study was therefore designed to evaluate the biochemical and genetic changes following administration of artesunate-amodiaquine (AS/AQ), Vita$\min C($ Vit $C)$ and their combination in P. berghei-infected mice.

In this study, administration of drug commenced on the 3rd day post-passaging after parasitaemia was confirmed in mice. When artesunate-amodiaquine as well as artesunate-amodiaquine + Vitamin C combination were administered to mice, parasitaemia dropped to less than $1 \%$ on day 1 however, on day 2 there was complete parasite clearance. This finding is expected as artesunate-amodiaquine is an established antimalarial drug whose efficacy has been proven and validated. Some studies have revealed that antioxidants such as Vitamin E and $C$ can interfere with the antiplasmodial effect of artemisinin derivatives $[11,12,28]$. However, in our study the coadministration of Vitamin $\mathrm{C}$ with artesunate-amodiaquine did not result in delayed parasite clearance as the parasites were completely cleared on day 2 . Our findings are in consonance with the study conducted by Ganiyu et al. [10]. The slightly higher parasitaemia in the Vitamin C treated mice compared with the untreated mice may be due to the free radical scavenging properties of Vitamin C. The Vitamin C may have promoted parasite survival by scavenging reactive oxygen species since the parasite is highly sensitive to these free radicals [7].
Our study showed that untreated mice ( $P$. bergheiinfected, but not treated) had elevated serum AST and ALT activities compared with the basal control (uninfected mice) as well as infected mice treated with Vitamin C, artesunate-amodiaquine and their combination. Malaria infection results in an increase in AST and ALT activities $[28,29]$. Elevated markers for hepatic function is expected during malaria infection as the liver plays central role in this disease. Liver changes associated with severe malaria includes sequestration of parasitized erythrocytes and deposition of haemozoin pigment [30,31]. Also, inflammatory stimuli such as immune response to disease can cause hepatic injury [32, 33]. Increased plasma AST and ALT activities serves as an excellent indicator of hepatic injury [34]. The elevated AST and ALT activities in the untreated mice may be as a result of leakage from injured hepatocytes by either abnormal cell activation induced by the Plasmodium parasites or simply by autoimmune defense system [35].

In addition, the decrease in AST and ALT activities in artesunate-amodiaquine and artesunate-amodiaquine + Vitamin C combination treated $P$. berghei-infected mice may be as a result of the antiplasmodial activity of the drug. The artesunate-amodiaquine + Vitamin C combination treated $P$. berghei-infected mice had a nonsignificantly lower AST activity in comparison with the mice treated with only artesunate-amodiaquine. Similarly, the Vitamin $C$ treated $P$. berghei-infected mice also had lower ALT and AST activities compared with the untreated mice. The water soluble antioxidant (Vitamin C) as well as in its combined form with the antiplasmodial drug may have mopped up free radicals and stabilized the membrane of the hepatocytes hence, a decrease in this enzyme activity. Artesunate-amodiaquine and its combination with Vitamin $C$ did not result in significant treatmentrelated changes in total protein level when compared with the mice infected with $P$. berghei without treatment (untreated). Albumin was increased in the artesunate-amodiaquine and artesunate-amodiaquine + Vitamin $C$ combination treated $P$. berghei-infected mice in contrast to the untreated mice. This observation may be attributed to the antiplasmodial activity of the drug. Some illnesses such as malaria have been reported to lead to nitrogen loss as a result of increased catabolism of albu$\min [36]$.

We observed a significant increase in total bilirubin level in the untreated mice in contrast to the mice treated with antimalarial drug, Vitamin $C$ and their combination. Similarly, a non-significant increase in direct bilirubin was also observed in the untreated mice compared with the other groups. Renner [37] as well as Yokoto and Calisei [38] reported that high level of bilirubin may be as a result of increased haemolysis, biliary tract obstruction, hepatocellular damage and jaundice. As an antioxidant, it 
is expected that Vitamin C would reduce significantly the level of bilirubin by protecting the hepatocytes and erythrocytes from oxidative damage. Aside hepatic injury, the relatively high level of bilirubin in $P$. berghei-infected mice treated with Vitamin $C$ may be as a result of haemolysis. The presence or absence of glutathione affects the antioxidant properties of Vitamin C in erythrocytes [39]. When glutathione is present, Vitamin C exhibits a synergistic antioxidant effect against cell toxicity mediated by haem [40]. In glutathione deficient erythrocytes as often seen in Plasmodium infected-erythrocytes, Vitamin $\mathrm{C}$ reacts with iron or compounds with iron to produce hydroxyl radical or hydrogen peroxide $[40,41]$. This interaction between Vita$\min \mathrm{C}$ and free radicals would eventually make the haemolytic mechanism in malarial more prominent $[40,41]$. Interestingly, the mice administered Vitamin $\mathrm{C}$ had the highest amount of indirect bilirubin which is commonly associated with haemolytic anaemia (data not shown). Furthermore, our result revealed that artesunate-amodiaquine + Vitamin $C$ combination treated $P$. berghei-infected mice had higher total and direct bilirubin levels compared with the mice treated with artesunate-amodiaquine only. The coadministration of artesunate-amodiaquine with Vitamin $\mathrm{C}$ may have resulted in haemolysis hence, an increase in total and direct bilirubin levels. Haemolysis has been associated with high levels of bilirubin [37, 38]. Previous study have shown that when blood was incubated with a therapeutic dose of artemether-lumefantrine and high/low concentrations of ascorbic acid, its viscosity and elasticity were significantly reduced [42]. This decrease in elasticity and viscosity may have resulted from low haematocrit caused by haemolysis [39]. This therapy involving coadministration of artesunate-amodiaquine with Vitamin C, may not be beneficial to specific individuals who are prone to have anaemia such as pregnant women, malnourished children in developing nations etc.

A significant increase in urea was observed in mice infected with $P$. berghei without treatment (untreated) when compared with the artesunate-amodiaquine and artesunate-amodiaquine + Vitamin C combination treated mice. However, changes in creatinine levels of the untreated mice was not significantly different from $P$. berghei-infected mice treated with Vitamin C, artesunate-amodiaquine and their combination. Increase in urea and creatinine levels in untreated $P$. berghei-infected mice has previously been noted [43]. P. berghei-infected mice treated with artesunate-amodiaquine +Vitamin C combination had a significantly lower urea when compared with the artesunate-amodiaquine treated mice. Creatinine and urea are diagnostic markers generally used to access kidney function. Renal failure together with severe anaemia and jaundice are usually common in severe malaria and they result in the disease being serious and often fatal [44].
The antiplasmodial activity of artesunate-amodiaquine may be responsible for the reduced urea and creatinine recorded in the group treated with this drug.

Hepatic SOD activity was higher in the artesunate-amodiaquine and artesunate-amodiaquine + Vitamin C combination treated $P$. berghei-infected mice compared with the untreated mice; however, this increase was only significant in the artesunate-amodiaquine + Vitamin C combination treated mice. A similar trend was also observed in renal SOD activity. Reduction in the SOD activity of the untreated mice may be that oxidative stress already implicated in malaria infection overwhelmed the SOD status of these mice. Treatment with antimalarial may have increased SOD activity via parasite clearance or direct stimulation of SOD synthesis. During malaria infection, there is an increase in SOD activity as the severity of malaria infection decreases $[45,46]$. Coadministration of ascorbic acid with artesunate-amodiaquine may have further increased SOD activity. Indeed Vitamin $C$ has been reported to increase antioxidant enzyme activity in tissues and prevent oxidative stress [47].

Hepatic $\mathrm{H}_{2} \mathrm{O}_{2}$ was significantly higher in the untreated mice relative to the treated mice. Similar trend was observed in the kidney but the increase in renal $\mathrm{H}_{2} \mathrm{O}_{2}$ was not significant. Also, in the untreated mice, hepatic MDA level was non-significantly increased compared with the treatment groups while renal MDA level was significantly increased. Again, oxidative stress in the untreated mice may be responsible for the increased $\mathrm{H}_{2} \mathrm{O}_{2}$ and MDA levels in these mice. Administration of antimalarial drugs may have resulted in decreased lipid peroxidation and $\mathrm{H}_{2} \mathrm{O}_{2}$ via parasite clearance. Our observation is contrary to the findings of Adebayo et al. [48] who observed an increase in MDA level of $P$. berghei-infected mice following administration of antimalarial drug. The differences in our findings may have resulted from the dosage of drug used, duration of study as well as the fact that Adebayo et al. [48] measured MDA level in serum while in this study it was measured in tissues. The antioxidant property of Vitamin C may have contributed to the lower MDA level in the artesunate-amodiaquine + Vitamin C combination treated $P$. berghei-infected mice when compared with the mice treated with only artesunate-amodiaquine.

Splenomegaly and hepatomegaly have been implicated in malaria infection. The antiplasmodial activity of artesunate-amodiaquine may have led to the decreased liver and spleen weight in artesunate-amodiaquine and artesunate-amodiaquine + Vitamin C combination treated $P$. berghei-infected mice compared with the Vitamin $C$ treated and untreated mice. However, coadministration of artesunate-amodiaquine with Vitamin $\mathrm{C}$ did not result in any significant changes in liver and spleen weight when compared with the group administered only 
artesunate-amodiaquine. Similarly, no significant changes was observed in the organ body weight of the untreated mice compared with the Vitamin C treated mice.

Our findings from this study revealed that catalase, $\mathrm{Cu}$ / Zn-SOD and GPx-1 mRNA expression in the bone marrow cells of mice infected with $P$. berghei without treatment (untreated) was down-regulated. This implies that malaria infection may not only result in oxidative stress via free radical generation but also down-regulates the expression of nuclear erythroid-2 like factor-2 (Nrf2) transcription factor dependent antioxidant enzymes. Nrf2 controls the expression of detoxification and antioxidant genes via binding to the antioxidant response element (AREs) that are mostly found in the promoter region of antioxidant (and other) genes in the nucleus, resulting in the transactivation of genes required for antioxidant enzyme synthesis $[49,50]$. The administration of Vitamin $C$ to $P$. berghei-infected mice up-regulated catalase, $\mathrm{Cu} /$ Zn-SOD and GPx-1 mRNA expression when compared with the untreated mice and this up-regulation was significant $(p<0.05)$ in catalase and GPx-1 genes. Indeed, Kim et al. [51] reported that ascorbic acid can activate the Nrf2/ARE signalling system. Additionally, Mikirova and Scimeca [52] revealed that intravenously administered Vitamin $C$ upregulated the gene coding for $\mathrm{Nrf2}$ in peripheral blood mononuclear cells. Result from this study also revealed that artesunate-amodiaquine significantly $(p<0.05)$ upregulated catalase, $\mathrm{Cu} / \mathrm{Zn}-\mathrm{SOD}$ and GPx-1 mRNA expression in comparison with the untreated mice. An indication that aside its antiplasmodial activity, artesunate-amodiaquine also improves the antioxidant enzyme status of erythrocytes. Furthermore, we observed that when the combination of Vitamin $\mathrm{C}$ and artesunate-amodiaquine was administered, there was a significant increase in the mRNA expression of these antioxidant enzymes compared with the mice treated only with artesunate-amodiaquine. This implies that artesunate-amodiaquine and Vitamin $\mathrm{C}$ may have a synergistic effect in up-regulating Nrf2dependent antioxidant enzymes.

\section{Conclusion}

Findings from this study have shown that the coadministration of artesunate-amodiaquine with Vitamin $C$ has the tendency to reduce parasite-induced oxidative stress in hepatic and renal tissues. However, its potential to increase bilirubin level when compared with administration of only artesunate-amodiaquine cannot be ignored. Furthermore, we have shown that coadministration of artesunate-amodiaquine with Vitamin C can significantly upregulate mRNA expression of Nrf2-dependent antioxidant enzymes genes in bone marrow cells. Thus, we conclude that coadministration of Vitamin C and artesunate-amodiaquine may be useful, at least in part, in the treatment of malaria in individuals who are prone to severe oxidative stress.

Acknowledgements The authors wish to appreciate Omotuyi O.I. (PhD) of the Bio-Computing Research Unit, Mols and Sims, Ado-Ekiti, Ekiti State, Nigeria for the technical assistance rendered during the gene expression study.

Author's contribution OE: Contributed in conceptualization of the study, data curation, formal analysis, investigation, resources, validation and writing the original draft of the manuscript. FI: Contributed in conceptualization of the study, validation, investigation and resources. ESO: Contributed in conceptualization of the study, review and editing of the manuscript, supervision and project administration. All authors read and approved the final manuscript.

Data availability The datasets used and/or analysed during the current study are available from the corresponding author on reasonable request.

\section{Compliance with ethical standards}

Conflict of interest The authors have no relevant financial or nonfinancial interests to disclose.

Code availability Not applicable.

Ethics approval Ethical approval for this study was granted by the Institutional Ethics Review Committee, Michael and Cecilia Ibru University (ethics approval number: MCIU/ETH/20/05) in accordance with the Guide for the Care and Use of Laboratory Animals published by the National Academy of Sciences (Eight edition).

Open Access This article is licensed under a Creative Commons Attribution 4.0 International License, which permits use, sharing, adaptation, distribution and reproduction in any medium or format, as long as you give appropriate credit to the original author(s) and the source, provide a link to the Creative Commons licence, and indicate if changes were made. The images or other third party material in this article are included in the article's Creative Commons licence, unless indicated otherwise in a credit line to the material. If material is not included in the article's Creative Commons licence and your intended use is not permitted by statutory regulation or exceeds the permitted use, you will need to obtain permission directly from the copyright holder. To view a copy of this licence, visit http://creativecommons .org/licenses/by/4.0/.

\section{References}

1. World malaria report 2020 (2020) 20 years of global progress and challenges. World Health Organization, Geneva. Licence: CC BY-NC-SA 3.0 IGO. Accessed 21 December 2020

2. Postma NS, Mommers EC, Eling WM, Zuidema J (1996) Oxidative stress in malaria: implication for prevention and therapy. Pharm World Sci 18:121-129. https://doi.org/10.1007/BF00717727 
3. Percário S, Moreira DR, Gomes BAQ, Ferreira MES, Gonçalve ACM, Laurindo PSOC et al (2012) Oxidative stress in Malaria. Int J Mol Sci 13:6346-16372. https://doi.org/10.3390/ijms131216346

4. Guha M, Kumar S, Choubey V, Maity P, Bandyopadhyay U (2006) Apoptosis in liver during malaria: role of oxidative stress and implication of mitochondrial pathway. FASEB J 20:439-449. https://doi.org/10.1096/fj.05-5338fje

5. Atamna H, Ginsburg H (1993) Origin of reactive oxygen species in erythrocytes infected with Plasmodium falciparum. Mol Biochem Parasitol 61:231-234. https://doi.org/10.1016/01666851(93)90069-a

6. Lavender OA, Ager AL (1993) Omega-3-fatty acids, oxidative stress and malaria. Omega-3-News 8:1-3

7. Ebohon O, Irabor F, Ebohon LO, Omoregie ES (2019) Therapeutic failure after regimen with artemether-lumefantrine combination therapy: a report of three cases in Benin City, Nigeria. Rev Soc Bras Med Trop 52:e20190163. https://doi. org/10.1590/0037-8682-0163-2019

8. World Health Organization (2006) Guidelines for the treatment of Malaria. WHO, Geneva

9. World Health Organization (2019) The use of artesunate-pyronaridine for the treatment of uncomplicated malaria. Licence: CC BY-NC-SA 3.0 IGO. Accessed 03 September 2020

10. Ganiyu KA, Akinleye MO, Tayo F (2012) A study of the effect of ascorbic acid on the antiplasmodial activity of artemether in Plasmodium berghei infected mice. J Appl Pharm Sci 2(6):96-100. https://doi.org/10.7324/JAPS.2012.2614

11. Meshnick SR, Tsang TW, Lin FB, Pan HZ, Chang CN, Kuypers F et al (1989) Activated oxygen mediates the antimalarial activity of qinghaosu. Prog Clin Biol Res 313:95104

12. Awodele O, Emeka PM, Akintonwa A, Aina O (2007) Antagonistic effect of Vitamin $E$ on the efficacy of artesunate against Plasmodium berghei infection in mice. Afr J Biol Res 10:51-57. https:// doi.org/10.4314/ajbr.v10i1.48971

13. Reitman S, Frankel S (1957) Colorimetric GOT and GPT determination. Am J Clin Pathol 28:56-63

14. Grant GH, Silverman LM, Christenson RH (1987) Amino acids and protein. In: Tietx NW (ed) Fundamental of clinical chemistry, 3rd edn. WB Saunders Company, Philadelphia, pp 328-329

15. Tietz NW (1995) Clinical guide to laboratory test, 3rd edn. WB Saunders Company, Philadelphia, pp 518-519

16. Walter M, Gerard H (1980) Ultramicromethod for the determination of conjugated and total bilirubin in serum or plasma. Microchem J 15:231-236

17. Annino JS (1960) Clinical chemistry principles and procedures, 2nd edn. Little Brown and Co, Boston, p 203

18. Wheatherburn MW (1967) Urease-Berthelot colorimetric method for in Vitaminro determination of urea. Anal Chem 39:971-974

19. Allen LC, Michalko K, Coons C (1982) More on cephalosporin interference with creatinine determinations. Clin Chem 28:555-556

20. Misra HP, Fridovich I (1972) The role of superoxide anion in the autooxidation of epinephrine and a simple assay for Superoxide dismustase. J Biol Chem 247:3170-3175

21. Buege JA, Aust SD (1978) Microsomal lipid peroxidation. Methods Enzymol 52:302-310

22. Woff SF (1994) Ferrous ion oxidation in the presence of ferric ion indicator xylenol orange for measurement of hydrogen peroxides. Methods Enzymol 233:182-189

23. Omotuyi OI, Nash O, Inyang OK, Ogidigo J, Enejoh O, Okpalefe O et al (2018) Flavonoid-rich extract of Chromolaena odorata modulate circulating GLP-1 in Wistar rats: computational evaluation of TGR5 involvement. Biotech 8:124. https://doi.org/10.1007/ s13205-018-1138-x
24. Ebohon O, Irabor F, Omoregie ES (2020) Sub-acute toxicity study of methanol extract of Tetrorchidium didymostemon leaf using biochemical analyses and gene expression in Wistar rats. Heliyon 6(6):e04313. https://doi.org/10.1016/j.heliyon.2020.e04313

25. Ye J, Coulouris G, Zaretskaya I, Cutcutache I, Rozen S, Madden T (2012) Primer-BLAST: a tool to design target-specific primers for polymerase chain reaction. BMC Bioinform 13:134

26. Rueden $C T$, Schindelin J, Hiner MC, DeZonia BE, Walter AE, Arena ET et al (2017) Image J2: ImageJ for the next generation of scientific image data. BMC Bioinform 18(1):529

27. Dodoo AN, Fogg C, Asiimwe A, Nartey ET, Kodua A et al (2009) Pattern of drug utilization for treatment of uncomplicated malaria in urban Ghana following national treatment policy change to artemisinin-combination therapy. Malar J 8:2. https ://doi.org/10.1186/1475-2875-8-2

28. Anyasor GN, Adeyemi O (2016) Oral administered ascorbic acid attenuated dihydroartemisinin anti-plasmodial activity and elicited hepatic injury in Plasmodium berghei strain Anka infected mice. J Exp Integr Med 6(3):139-142. https://doi.org/10.5455/ jeim.060916.or.159

29. lyawe HOT, Onigbinde AO, Aina OO (2006) Effect of chloroquine and ascorbic acid interation on the oxidative status of Plasmodium berghei infected mice. Int J Pharmacol 2(1):1-4. https://doi. org/10.3923/ijp.2006.1.4

30. Rupani $A B, A$ marapurkar $A D$ (2009) Hepatic changes in fatal malaria: an emerging problem. Ann Trop Med Parasitol 103:1 19127. https://doi.org/10.1179/136485909X385054

31. Whitten R, Milner DA, Yeh MM, Kamiza S, Molyneux ME, Taylor TE (2011) Liver pathology in Malawian children with fatal encephalopathy. Human Pathol 42:1230-1239. https://doi.org/10.1016/j. humpath.2010.11.019

32. Vanderberg JP, Frevert U (2004) Intravital microscopy demonstrating antibody-mediated immobilisation of Plasmodium berghei sporozoites injected into skin by mosquitoes. Int J Parasitol 34(9):991-996. https://doi.org/10.1016/j.ijpara.2004.05.005

33. Pan MH, Lai CS, Ho CT (2010) Anti-inflammatory activity of natural dietary flavonoids. Food Funct 1(1):15-31. https://doi. org/10.1039/c0fo00103a

34. Schomaker S, Warner R, Bock J, Johnson K, Potter D, Winkle JV et al (2013) Assessment of emerging biomarkers of liver injury in human subjects. Toxicol Sci 32:276-283. https://doi. org/10.1093/toxsci/kft009

35. Guthrow CE, Morris JF, Day JW (2007) Enhanced non-enzymatic glycosylation of human serum albumin. Q J Med 30-38

36. Adekunle AS, Adekunle OC, Egbewale BE (2007) Serum status of selected biochemical parameters in malaria: an animal model. Biomed Res 18(2):109-113

37. Renner EL (1995) Liver function test. Balliere J Clin Gastroenterol 9:661-772

38. Yokoto USC, Calisei T (2006) Malaria parasite and their relationships with their host. Malar Res 44:265-273

39. Marwaha N (2016) Ascorbic acid co-administration with artemisinin based combination therapies in falciparum malaria. Indian J Med Res 143:539-541. https://doi.org/10.4103/09715916.187100

40. Li SD, Su YD, Li M, Zou CG (2006) Hemin-mediated hemolysis in erythrocytes: effects of ascorbic acid and glutathione. Acta Biochim Biophys Sin (Shanghai) 38:63-69. https://doi.org/10.1 111/j.1745-7270.2006.00127.x

41. Mendiratta S, Qu Z, May JM (1998) Erythrocyte defenses against hydrogen peroxide: the role of ascorbic acid. Biochim Biophys Acta 1380:389-395. https://doi.org/10.1016/s0304 $-4165(98) 00005-1$

42. McKoy MG, Kong-Quee P III, Pepple DJ (2016) In vitro effects of co-incubation of blood with artemether/lumefantrine and 
Vitamin C on the viscosity and elasticity of blood. Indian J Med Res 143:577-580. https://doi.org/10.4103/0971-5916.187105

43. Momoh J, Longe AO, Campbell CA (2014) In vivo anti-plasmodial and in vitro antioxidant activity of ethanolic leaves extract of Alstonia boonie (ewe ahun) and its effect on some biochemical parameters in swiss albino mice infected with Plasmodium berghei NK 65. Eur Sci J 10(18):68-82

44. Miller LH, Baruch DI, Marsh K, Doumbo OK (2002) The pathogenic basis of malaria. Nature 415:673-679. https://doi. org/10.1038/415673a

45. Olayemi SO, Arikawe AP, Akinyede A, Oreagba Al, Awodele O (2012) Effect of malarial treatment on biochemical parameters and plasma $\mathrm{pH}$ of mice infected with Plasmodium berghei. Int J Pharmacol 8(6):549-554. https://doi.org/10.3923/ ijp.2012.549.554

46. lyawe HOT, Onigbinde AO (2009) Impact of Plasmodium berghei and chloroquine on haematological and antioxidants indices in mice. Asian J Biochem 4:30-35. https://doi.org/10.3923/ ajb.2009.30.35

47. Akbari A, Jelodar G, Nazifi S, Sajedianfard J (2016) An overview of the characteristics and function of Vitamin $C$ in various tissues: relying on its antioxidant function. Zahedan J Res Med Sci 18(11):e4037. https://doi.org/10.17795/zjrms-4037

48. Adebayo AH, Okenze GN, Yakubu OF, Abikoye ME (2018) Biochemical and histopathological effects of coadministration of amodiaquine, artesunate and selenium on Plasmodium berghei infected mice. Asian J Pharm Clin Res 11(3):1-4. https://doi. org/10.22159/ajpcr.2018.v11s3.29963
49. Martín MA, Ramos S, Granado-Serrano AB, Rodríguez-Ramiro I, Trujillo M, Bravo L et al (2010) Hydroxytyrosol induces antioxidant/detoxificant enzymes and Nrf2 translocation via extracelular regulated kinases and phosphatidylinositol-3kinase/protein kinase B pathways in HepG2 cells. Mol Nutr Food Res 54:956966. https://doi.org/10.1002/mnfr.200900159

50. Smith RE, Tran K, Smith CC, McDonald M, Shejwalkar P, Hara K (2016) The role of the Nrf2/ARE antioxidant system in preventing cardiovascular diseases. Diseases 4(34):1-20. https://doi. org/10.3390/diseases4040034

51. Kim SR, Ha YM, Kim YM, Park EJ, Kim JW, Park SW et al (2015) Ascorbic acid reduces HMGB1 secretion in lipopolysaccharideactivated RAW 264.7 cells and improves survival rate in septic mice by activation of Nrf2/HO-1 signals. Biochem Pharmacol 95:279-289. https://doi.org/10.1016/j.bcp.2015.04.007

52. Mikirova NA, Scimeca RC (2016) Intravenous high-dose ascorbic acid reduces the expression of inflammatory markers in peripheral mononuclear cells of subjects with metabolic syndrome. J Translational Sci 2(3):188-195. https://doi.org/10.15761/ JTS.1000139

Publisher's Note Springer Nature remains neutral with regard to jurisdictional claims in published maps and institutional affiliations. 